\title{
PENGARUH PENDEKATAN MATEMATIKA REALISTIK TERHADAP KEMAMPUAN BERFIKIR KREATIF DAN PEMECAHAN MASALAH MATEMATIKA SISWA KELAS VII
}

\author{
Abdul Halim ${ }^{1}$, Asmin $^{2}$, Faiz Ahyaningsih ${ }^{2}$
}

\begin{abstract}
ABSTRAK
Penelitian ini bertujuan untuk mengetahui pengaruh pendekatan matematika realistik terhadap kemampuan berpikir kreatif matematika siswa, untuk mengetahui pengaruh pendekatan matematika realistik terhadap kemampuan pemecahan masalah matematika siswa, untuk mengetahui interaksi antara pembelajaran dengan kemampuan awal matematika (KAM) terhadap kemampuan berpikir kreatif matematika siswa, serta ntuk mengetahui interaksi antara pembelajaran dan kemampuan awal matematika (KAM) terhadap kemampuan pemecahan masalah matematika siswa. Data diperoleh melalui tes KAM, tes soal berpikir kreatif dan pemecahan masalah siswa. Data dianalisis dengan uji ANAVA dua jalur. Berdasarkan hasil analisis (ANAVA) diperoleh hasil penelitian dengan nilai signifikan (sig) $\alpha=$ 0,000 disimpulkan bahwa terdapat pengaruh pendekatan pembelajaran matematika realistik terhadap kemampuan berpikir kreatif siswa dan nilai signifikansi interaksinya yaitu 0,488 berarti tidak terdapat interaksi pendekatan pembelajaran dan KAM terhadap kemampuan berpikir kreatif siswa. Selanjutnya untuk kemampuan pemecahan masalah nilai signifikan (sig) $\alpha=0,000$ bahwa terdapat pengaruh pendekatan pembelajaran matematika realistik terhadap kemampuan pemecahan masalah matematis siswa dan nilai signifikansi interaksi yaitu 0,337 karena nilai signifikansi lebih besar dari nilai taraf signifikan 0,05 jadi tidak cukup bukti untuk menolak Ho dengan kata lain Ho diterima, berarti tidak terdapat interaksi pendekatan pembelajaran dan KAM terhadap kemampuan pemecahan masalah matematis siswa.
\end{abstract}

Kata Kunci: Pendekatan Matematika Realistik, Kemampuan Berfikir Kreatif, Kemampuan Pemecahan Masalah, Kemampuan Awal Matematika (KAM)

\section{PENDAHULUAN}

Komisi Matematika sebagai salah satu mata pelajaran yang memegang peranan yang sangat penting dalam pendidikan. Karena selain dapat mengembangkan pemikiran kreatif, kreatif, sistematis, dan logis, matematika juga telah memberikan kontribusi dalam kehidupan sehari-hari mulai dari hal yang sederhana seperti perhitungan dasar (basic calculation) sampai hal yang kompleks dan abstrak seperti penerapan analisis numerik dalam bidang teknik dan sebagainya.

Peningkatan kualitas pembelajaran matematika di Indonesia,sesuai tuntutan kurikulum 2013 memerlukan berbagai upaya. Rancangan pendidikan yang memberi kesempatan untuk peserta didik mengembangkan potensi dirinya dalam suasana belajar yang menyenangkan dan sesuai dengan kemampuan dirinya. Seiring dengan perkembangan internet tersebut maka strategi pembelajaran pun bergeser dan muncul berbagai strategi pembelajaran berbasis teknologi informasi dan komunikasi dari model e-learning, smart classroom technology, virtual classroom, belded learning, dll (Fitri \& Zahari, 2019). Guru berlaku sebagai fasilitator dalam pembelajaran. Proses penilaian berbasis proses dan output serta

${ }^{1}$ Corresponding Author: Abdul Halim

Program Magister Pendidikan Matematika, Universitas Negeri Medan, Medan, 20221, Indonesia

E-mail: sahabathalimmunthe@gmail.com

${ }^{2}$ Co-Author: Asmin \& Faiz Ahyaningsih

Program Studi Pendidikan Matematika, Universitas Negeri Medan, Medan, 20221, Indonesia menyeimbangkan softskill dan hardskill. Salah satu hardskill yang dituntut adalah kemampuan berpikir kreatif.

Salah satu doing math yang erat kaitannya dengan karakteristik matematika adalah kemampuan berpikir kreatif dan kemampuan pemecahan masalah. Kemampuan berpikir kreatif ditandai dengan siswa yang lebih condong untuk mengemukakan pertanyan yang dapat membantunya untuk menemukan jawaban ketika menyelesaikan sebuah masalah. Siswa akan mudah memiliki kemampuan berpikir kreatif matematika jika saat ia menerima pelajaran, cara yang diberikan kepadanya dapat menumbuhkembangkan daya berpikir dan berkreativitasnya melalui sebuah strategi dan pendekatan yang digunakan guru.

Begitu juga dengan pentingnya memiliki kemampuan pemecahan masalah dalam menyelesaikan masalah matematika. Dalam memecahkan masalah tentu ada masalah yang akan diselesaikan. Masalah dapat diartikan sebagai suatu situasi, dimana seseorang diminta menyelesaikan persoalan yang belum pernah dikerjakan, dan belum memahami pemecahannya. Suatu soal matematika atau pernyataan akan merupakan masalah apabila tidak terdapat aturan atau hukum tertentu yang segera dapat digunakan untuk menjawab atau menyelesaikannya. Suatu masalah disebut masalah matematika jika prosedur matematika seperti prosedur aritmatika dan aljabar dibutuhkan untuk memecahkannya.

Suasana belajar yang dikembangkan selama ini juga masih menggunakan model pembelajaran konvensional dan cenderung siswa dituntut kompetitif dimana guru masih belum menata dan menciptakan suasana belajar 
Vol. 12, No. 1, Juni 2020

yang baik serta masih berpusat pada guru.Pembelajaran yang berlangsung belum melibatkan siswa secara aktif, tidak mengakomodir perbedaan individu, konsep diri atau melihat kepribadian anak, hal ini dapat dilihat dari pemilihan strategi yang sama untuk sekelompok siswa yang tentu memiliki kebutuhan dan karakteristik yang berbeda.

Guru yang baik adalah guru yang memiliki kompetensi pedagogi. Kompetensi pedagogi memiliki tujuh aspek yaitu (1) menguasai karakteristik peserta didik; (2) menguasai teori belajar dan prinsip-prinsip pembelajaran yang mendidik; (3) pengembangan kurikulum; (4) kegiatan pembelajaran yang mendidik; (5) pengembangan potensi peserta didik; (6) komunikasi dengan peserta didik; dan (7) Penilaian dan evaluasi.

Anak anak lebih merasa tertarik jika langsung melihat proses matematika dilapangan atau realistik sehingga mereka selalu menggunakan matematika dengan kebutuhnan pribadi mereka di lapangan. Oleh karena itu, Pendekatan Matematika Realistik (PMR) merupakan salah satu pembelajaran yang baik dalam pembelajaran matematika, Karena pada pembelajaran ini mengaitkan materi pelajaran dengan kehidupan sehari-hari, sehingga peserta didik dapat mengaplikasikan materi pelajaran dengan kehidupan sehari-hari. Menjadikan siswa lebih terangsang dalam belajar matematika.

Berdasarkan uraian latar belakang tersebut, peneliti berminat untuk melakukan penelitian mengungkapkan apakah ada pengaruh pengaruh pendekatan matematika realistik terhadap kemampuan berfikir kreatif dan pemecahan masalah matematika siswa di kelas VIII.

\section{KAJIAN TEORITIS}

\subsection{Kemampuan Berpikir Kreatif}

Resiliensi Semiawan (2010) yang mengemukakan bahwa kreativitas merupakan kemampuan untuk memberikan gagasan baru dan menerapkannya dalam pemecahan masalah. Ini berarti bahwa seseorang yang memiliki daya kreativitas yang tinggi adalah seseorang yang dapat menciptakan atau memberikan gagasan yang baru dalam menyelesaikan masalah. Dalam matematika contohnya, siswa dapat menggunakan kreativitasnya dalam membuat cara penyelesaian yang baru dan berbeda dengan yang lain, tetapi masih berada dalam konteks yang benar. Dari pengertian diatas, disimpulkan bahwa kreativitas adalah kemampuan yang dimiliki seseorang untuk menciptakan sesuatu yang baru berupa ide dan gagasan yang menghasilkan karya yang baru.

Adapun proses kreatif hanya akan terjadi jika dibangkitkan melalui masalah yang memacu pada lima macam prilaku kreatif, sebagaimana yang dipaparkan oleh Parnes dalam Rachmawati dan Kurniati (2010) sebagai berikut :

a. Fluency (kelancaran), yaitu kemampuan mengemukakan ide yang serupa untuk memecahkan suatu masalah.

b. Flexibility (keluwesan), yaitu kemampuan untuk mengahasilkan berbagai macam ide guna memecahkan suatu masalah di luar kategori yang biasa.

c. Orginality (keaslian), yaitu kemampuan memberikan respon yang unik atau luar biasa.

d. Elaboration (kejelasan), yaitu kemampuan menyatakan pengarahan ide secara terperinci untuk mewujudkan ide menjadi kenyataan.

1.2 Kemampuan Pemecahan Masalah Matematika

Dalam Hudojo (2005) mengemukakan bahwa pemecahan masalah merupakan suatu hal yang sangat esensial dalam pembelajaran matematika di sekolah, disebabkan: (1) siswa menjadi terampil menyeleksi informasi yang relevan, kemudian menganalisanya dan akhirnya meneliti hasilnya; (2) kepuasan intelektual akan timbul dari dalam; (3) potensi intelektual siswa meningkat. Dengan demikian, sudah seharusnyalah pemecahan masalah ini mendapat perhatian khusus, mengingat peranannya yang sangat penting dalam mengembangkan potensi intelektual siswa.

Pemecahan masalah dianggap merupakan standar kemampuan yang harus dimiliki para siswa setelah menyelesaikan suatu pembelajaran. Kemampuan pemecahan masalah merupakan kemampuan yang merupakan target pembelajaran matematika yang sangat berguna bagi siswa dalam kehidupannya. Hal ini dikarenakan dengan adanya kemampuan pemecahan masalah yang di berikan siswa, maka menunjukkan bahwa suatu pembelajaran telah mampu atau berhasil membantu siswa untuk mencapai tujuan yang akan dicapai.

Polya dalam Dinda (2012), secara operasional pemecahan masalah memiliki tahap-tahap: (1) Memahami masalah, (2) Merencanakan pemecahannya, (3) Menyelesaikan masalah sesuai dengan rencana (4) Memeriksa kembali prosedur dan hasil penyelesaian.

\subsection{Pendekatan Matematika Realistik}

Pendekatan Matematika Realistik (PMR) adalah sebuah pendekatan pembelajaran matematika yang harus selalu menggunakan masalah sehari-hari (Wijaya, 2012). Aktivitas pembelajaran matematika dalam prinsip PMR tidak harus selalu berupa masalah yang ada di dunia nyata tapi biasa ditemukan dalam kehidupan sehari-hari siswa.Suatu masalah disebut realistik jika masalah tersebut dapat dibayangkan atau nyata dalam pikiran siswa.Suatu cerita rekaan, permainan atau bahkan bentuk formal matematika bisa digunakan sebagai masalah realistik. Pada PMR, permasalahan realistik digunakan sebagai pondasi dalam membangun konsep matematika disebut juga sebagai sumber untuk pembelajaran.

Sedangkan karakteristiksiswa yang tepat diberikan PMR yaitu :(1) aktif memahami masalah/soal, (2) aktif bermatematika, (3) aktif bertanya, (4) aktif menemukan model/ strategi/ prosedur bermatematika (5) aktif menyelesaikan soal, (6) aktif membandingkan model/ strategi/ prosedur. Ide utama dari model pembelajaran RME adalah manusia harus diberikan kesempatan untuk menemukan kembali (reinvent) ide dan konsep matematika dengan bimbingan orang dewasa (Gravemeijer, 1994). Upaya untuk menemukan kembali ide dan konsep matematika ini dilakukan 
dengan memanfaatkan realita dan lingkungan yang dekat dengan anak.

Penjelasan lebih lanjut dikemukakan oleh Van den Heuvel (Wijaya, 2012) bahwa penggunaan kata "realistik" sebenarnya berasal dari bahasa Belanda "zich realiseren" yang berarti untuk dibayangkan. Jadi, RME tidak hanya menunjukkan adanya keterkaitan dengan dunia nyata tetapi lebih mengacu pada fokus pendidikan matematika realistik yaitu penekanan pada penggunaan situasi yang dapat dibayangkan oleh siswa.

Langkah-langkah kegiatan inti pembelajaran matematika realistik dalam penelitian ini adalah sebagai berikut.

\section{Langkah 1: Memahami masalah kontekstual}

Guru memberikan masalah (soal) kontekstual dan siswa diminta untuk memahami masalah tersebut. Guru menjelaskan soal atau masalah dengan memeberikan petunjuk/saran seperlunya (terbatas) terhadap bagianbagian tertentu yang dipahami siswa. Pada langkah ini karakteristik PMR yang diterapkan adalah karakteristik pertama. Selain itu pemberian masalah kontekstual berarti memberi peluang terlaksananya prinsip pertama dari PMR.

\section{Langkah 2: Menyelesaikan masalah kontekstual}

Siswa secara individual disuruh menyelesaikan masalah kontekstual pada Buku Siswa atau LKS dengan caranya sendiri. Cara pemecahan dan jawaban masalah yang berbeda lebih diutamakan. Guru memotivasi siswa untuk menyelesaikan masalah tersebut dengan memberikan pertanyaan-pertanyaan penuntun untuk mengarahkan siswa memperoleh penyelesaian soal tersebut. Misalnya: bagaimana kamu tahu itu, bagaimana caranya, mengapa kamu berpikir seperti itu dan lain-lain. Pada tahap ini siswa dibimbing untuk menemukan kembali tentang idea tau konsep atau definisi dari soal matematika. Di samping itu pada tahap ini siswa juga diarahkan untuk membentuk dan menggunakan model sendiri untuk membentuk dan menggunakan model sendiri untuk memudahkan menyelesaikan masalah (soal). Guru diharapkan tidak member tahu penyelesaian soal atau masalah tersebut, sebelum siswa memperoleh penyelesaiannya sendiri. Pada langkah ini semua prinsip PMR muncul, sedangkan karakteristik PMR yang muncul adalah karakteristik ke-2, menggunakan model.

Langkah 3: Membandingkan dan mendiskusikan jawaban

Siswa diminta untuk membandingkan dan mendiskusikan jawaban mereka dalam kelompok kecil. Setelah itu hasil dari diskusi itu dibandingkan pada diskusi kelas yang dipimpin oleh guru. Pada tahap ini dapat digunakan siswa untuk melatih keberanian mengemukakan pendapat, meskipun berbeda dengan teman lain atau bahkan dengan gurunya. Karakteristik PMR yang muncul pada tahap ini adalah penggunaan idea tau kontribusi siswa, sebagai upaya untuk mengaktifkan siswa melalui optimalisasi interaksi antara siswa dengan siswa, antara guru dengan siswa dan antara siswa dengan sumber belajar.

\section{Langkah 4: Menarik Kesimpulan}

Berdasarkan hasil diskusi kelompok dan diskusi kelas yang dilakukan, guru mengarahkan siswa untuk menarik kesimpulan tentang konsep, definisi, teorema, prinsip atau prosedur matematika yang terkait dengan masalah kontekstual yang baru diselesaikan. Karakteristik PMR yang muncul pada langkah ini adalah menggunakan interaksi antara guru dengan siswa.

Menurut Suwarsono : (2001) terdapat beberapa kekuatan atau kelebihan dari matematika realistik, yaitu :

a. Pembelajaran matematika realistik memberikan pengertian yang jelas kepada siswa tentang kehidupan sehari-hari dan kegunaan pada umumnya bagi manusia.

b. Pembelajaran metematika realistik memberikan pengertian yang jelas kepada siswa matematika adalah suatu bidang kajian yang dikonstruksi dan dikembangkan sendiri oleh siswa tidak hanya oleh mereka yang disebut pakar dalam bidang tersebut.

c. Pembelajaran matematika realistik memberikan pengertian yang jelas kepada siswa cara penyelesaian suatu soal atau masalah tidak harus tunggal dan tidak harus sama antara yang satu dengan orang yang lain. Setiap orang bisa menemukan atau menggunakan cara sendiri, asalkan orang itu sungguh-sungguh dalam mengerjakan soal atau masalah tersebut. Selanjutnya dengan membandingkan cara penyelesaian yang satu dengan cara penyelesaian yang lain, akan bisa diperoleh cara penyelesaian yang tepat, sesuai dengan tujuan dari proses penyelesaian masalah tersebut.

d. Pembelajaran matematika realistik memberikan pengertian yang jelas bagi siswa bahwa proses pembelajaran matematika merupakan sesuatu yang utama.Dan orang harus menjalani proses itu serta berusaha untuk menemukan sendiri konsepkonsep matematika.Dengan bantuan pihak lain yang sudah lebih tahu (misalnya guru). Tanpa kemauan untuk menjalani sendiri proses tersebut, pembelajaran yang bermakna tidak akan tercapai..

\section{METODE PENELITIAN}

Penelitian ini mengambil dua kelas parallel secara acak dengan menerapkan pembelajaran yang berbeda yaitu kelas eksperimen dan kelas kontrol .Kelas eksperimen diberi perlakuan dengan menerapkan perlakuan pendekatan PMR dan kontrol diberi perlakuan dengan menerapkan pembelajaran konvensional. Desain eksperimen dalam penelitian ini dapat dilihat pada Tabe 1 berikut ini.

Tabel 1. Desain Penelitian

\begin{tabular}{lcc}
\hline Kelompok & Variabel Bebas & Postest \\
\hline Eksperimen & $\mathrm{X}$ & $\mathrm{O}$ \\
\hline Kontrol & & $\mathrm{O}$ \\
\hline
\end{tabular}

Keterangan:

$\mathrm{X}$ : Perlakuan berupa pendekatan PMR dengan menggunakan peta konsep

O: Postest kelompok eksperimen dan kelompok kontrol 
Populasi dalam penelitian ini adalah seluruh siswa MTs Swasta At-taufiqurrahman tahun pelajaran 2017/2018 yang berjumlah 174 siswa. Sampel Penelitian diambil secara random (acak) dua kelas yaitu sebagai kelas eksperimen dan kelas kontrol. Kelas eksperimen adalah kelas yang diberi perlakuan pendekatan PMR. Dan kelas kontrol adalah kelas yang diberi pembelajaran berbasis konvensional.Sampel dalam penelitian ini adalah kelas VIII-1 dan kelas VIII2. Kelas VIII-1 sebagai kelas eksperimen berjumlah 25 siswa dan kelas VIII-2 sebagai kelas kontrol berjumlah 25 siswa.

Instrumen Penelitian yang digunakan ialah tes soal berpikir kreatif dan pemecahan masalah, yang digunakan pada postes untuk mengukur kemampuan siswa yang digunakan untuk mengetahui berpikir kreatif dan pemecahan masalah. Soal tes yang akan diberikan sebanyak 4 soal yang berbentuk uraian karena tes bentuk uraian dapat mewakili semua indikator dari kemampuan berpikir kreatif matematis siswa. Penelitian ini dilengkapi dengan lembar pengamatan terhadap aktivitas guru dan siswa terutama kemampuan pedagogi guru dalam pendekatan matematika realistik, serta lembar pengamatan terhadap keterampilan pemecahan masalah siswa dan kemampuan berpikir kreatif selama bekerja dalam kelompok berdasarkan pengetahuan prosedur.

\section{HASIL PENELITIAN}

Kemampuan pemecahan masalah matematis siswa diperoleh dari hasil postes pada kelas eksperimen dan kelas kontrol. Berdasarkan hasil postes yang diberikan saat pembelajaran di kelas eksperimen dan kelas kontrol, selanjutnya dilakukan perhitungan rata-rata dan standar deviasi hasil tes kemampuan berpikir kreatif siswa. Adapun hasil tes kemampuan berpikir kreatif siswa dapat dilihat pada gambar 1 berikut ini.

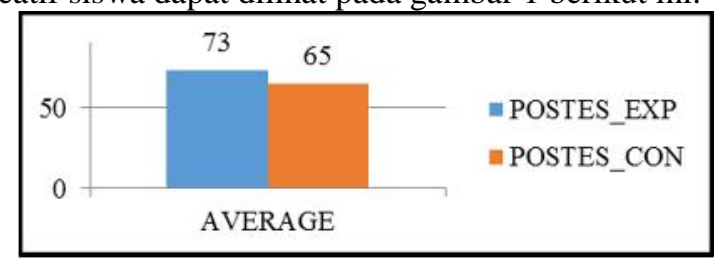

Gambar 1. Grafik Rata-rata Postes Kemampuan Berpikir Kreatif Matematis Kelas Eksperimen dan Kelas Kontrol

Adapun hasil tes kemampuan berpikir kreatif siswa berdasarkan indikator dapat dilihat pada Tabel 2 berikut ini.

Tabel 2. Hasil Postes Kemampuan Berpikir Kreatif Berdasarkan Indikator

\begin{tabular}{|c|c|c|}
\hline \multirow[b]{2}{*}{ Indikator } & \multicolumn{2}{|c|}{ Rata-rata } \\
\hline & $\begin{array}{c}\text { Postes Kelas } \\
\text { Eksperimen }\end{array}$ & $\begin{array}{c}\text { Postes Kelas } \\
\text { Kontrol }\end{array}$ \\
\hline $\begin{array}{l}\text { Berpikir Fluency } \\
\text { (kelancaran): mampu } \\
\text { menjawab dengan } \\
\text { sejumlah jawaban }\end{array}$ & 7.48 & 6.96 \\
\hline Berpikir Luwes: & 9.84 & 9.52 \\
\hline
\end{tabular}

mampu

menyelesaikan

masalah dengan

bermacam-macam

cara penyelesaian

Berpikir Orisinil:

mampu memberikan

gagasan yang baru

11.32

dalam menyelesaikan

masalah

Berpikir Elaboratif:

cenderung

memberikan jawaban

yang luas dan

7.9

memuaskan

Tabel 2 menunjukkan bahwa rata-rata kemampuan berpikir kreatif siswa setelah diberikannya pembelajaran matematika realistik lebih baik daripada rata-rata kekmapuan berpikir kreatif siswa yang diberikan pembelajaran konvensional. Rata-rata postes kelas eksperimen dan postes kelas kontrol untuk indikator pertama yaitu 7,48 dan 6,96, indikator kedua yaitu 9.84 dan 9.52, indikator ketiga yaitu 11.3 dan 10.24, indicator keempat yaitu 7.9 dan 5.8.

Berdasarkan uraian di atas, dapat dilihat bahwa rata-rata postes kemampuan berpikir kreatif siswa kelas eksperimen tiap indikator lebih baik daripada rata-rata postes kemampuan berpikir kreatif siswa kelas kontrol. Hal ini menunjukkan bahwa adanya dampak yang lebih baik pada siswa yang diberi pembelajaran matematika realistik.

Hasil pengujian menujukkan bahwa kelompok data kemampuan berpikir kreatif berasal dari populasi yang berdistribusi normal dengan varians data homogen, maka selanjutnya dilakukan analisis statistik anava dua jalur.

Tabel 3. Hasil Uji ANAVA Kemampuan Berpikir Kreatif Siswa

\begin{tabular}{lrrrrr}
\hline \multicolumn{5}{c}{ Test of Between-Subjects Effects } \\
\hline \multicolumn{5}{c}{ Dependent variable: Kemampuan Berpikir Kreatif } \\
\hline $\begin{array}{l}\text { Type III } \\
\text { Sum of } \\
\text { Squares }\end{array}$ & Df & $\begin{array}{c}\text { Mean } \\
\text { Square }\end{array}$ & F & Sig. \\
\hline $\begin{array}{l}\text { Corrected } \\
\text { Model }\end{array}$ & $4607.280^{3}$ & 5 & 921.456 & 37.196 & .000 \\
\hline Intercept & 151919.582 & 1 & 151919.582 & 6132.534 & .000 \\
\hline KAM & 3738.809 & 2 & 1869.405 & 75.462 & .000 \\
\hline Pembel & 525.523 & 1 & 525.523 & 21.214 & .000 \\
\hline $\begin{array}{l}\text { KAM } * \\
\text { Pembel }\end{array}$ & 36.151 & 2 & 18.075 & .730 & .488 \\
\hline Error & 1090.000 & 44 & 24.773 & & \\
\hline Total & 244576.000 & 50 & & & \\
\hline $\begin{array}{l}\text { Corrected } \\
\text { Total }\end{array}$ & 5697.280 & 49 & & & \\
\hline a. R Squared $=.809$ (Adjusted R Squared = .787 & & & \\
\hline
\end{tabular}

Berdasarkan hasil uji ANAVA, kemampuan berpikir kreatif siswa pada Tabel 3 maka F hitung pada faktor pendekatan pembelajaran matematika realistik adalah 21.214 dan nilai signifikan (sig) $\alpha=0.000$. Karena taraf nilai signifikan kemampuan berpikir 
Vol. 12, No. 1, Juni 2020

kreatif siswa lebih kecil dari $\alpha=0.05$ maka dapat disimpulkan bahwa terdapat pengaruh pendekatan pembelajaran matematika realistik terhadap kemampuan berpikir kreatif siswa.

Untuk interaksi dari Tabel 3 terlihat bahwa faktor pembelajaran dan KAM hasil analisis, diperoleh nilai F untuk interaksi pembelajaran dan KAM yaitu 0.730 dan nilai signifikansi yaitu 0.488 . Karena nilai signifikansi lebih besar dari nilai taraf signifikan 0.05 jadi tidak cukup bukti untuk menolak Ho dengan kata lain $\mathrm{H}_{1}$ diterima, berarti tidak terdapat interaksi pendekatan pembelajaran dan KAM terhadap kemampuan berpikir kreatif siswa. Lebih jelas dapat dilihat pada gambar berikut:

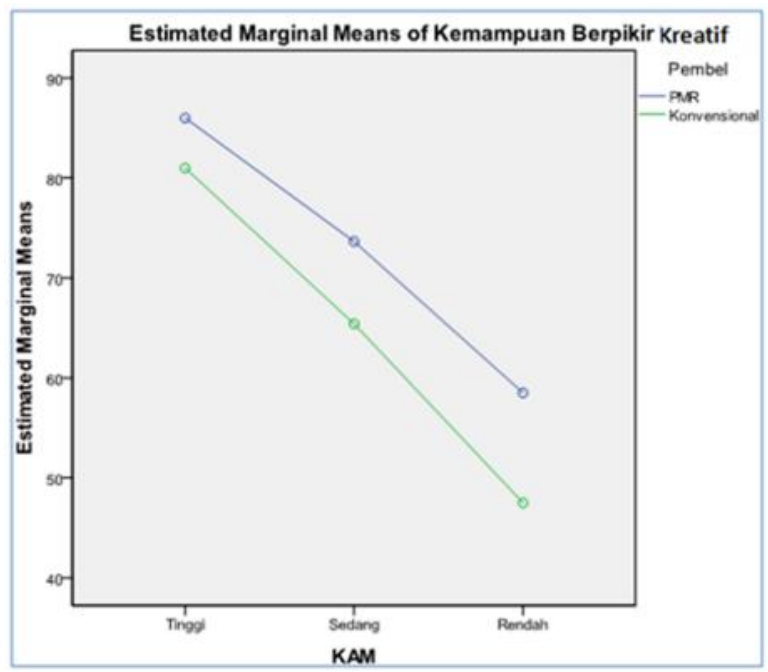

Gambar 2. Interaksi Pendekatan Pembelajaran dan

Kemampuan Awal Matematika Terhadap Kemampuan Berpikir Kreatif siswa

Gambar 2 memperlihatkan bahwa pendekatan pembelajaran matematika realistik lebih berpengaruh dalam mencapai potensi kemampuan berpikir kreatif karena skor rataan yang diperoleh siswa di kelas ini lebih tinggi dibandingkan dengan skor rataan yang diperoleh di pembelajaran konvensional. Sehingga tidak terdapat interaksi pendekatan pembelajaran dankemampuan awal matematika siswa terhadap kemampuan berpikir kreatifsiswa. Berdasarkan beberapa uraian diatas maka telah didapatkan jawaban tentang apa yang menjadi pertanyaan-pertanyaan yang harus diteliti dalam penelitian ini. Bahwa antara kedua garis tidak berpotongan atau bersinggungan maka kuat dugaan tidak terdapat interaksi antara model pembelajaran dan KAM terhadap kemampuan berpikir kreatif matematis siswa.

Berdasarkan hasil postes diberikan setelah pembelajaran kepada kedua kelas, yaitu kelas eksperimen untuk pembelajaran pendekatan matematika realistik dan kelas kontrol untuk pembelajaran biasa, selanjutnya dilakukan perhitungan rata-rata dan standar deviasi hasil tes kemampuan pemecahan masalah matematis siswa. Adapun hasil tes kemampuan pemecahan masalah matematis siswa dapat dilihat pada Gambar 3 berikut ini.

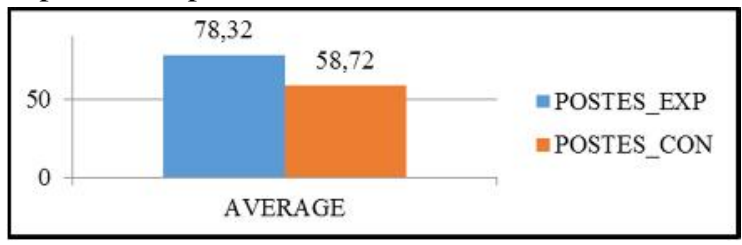

Gambar 3. Grafik Rata-rata Postes Kemampuan

Pemecahan Masalah Matematis Kelas Eksperimen dan Kelas Kontrol

Besarnya pengaruh hasil tes kemampuan pemecahan masalah matematis siswa juga dapat dilihat berdasarkan indikator pada kemampuan pemecahan masalah matematis. Adapun hasil tes kemampuan pemecahan masalah matematis siswa berdasarkan indikator dapat dilihat pada Tabel 4 berikut ini.

Tabel 4. Hasil Postes Kemampuan Pemecahan Masalah Matematis Berdasarkan Indikator

\begin{tabular}{lcc}
\hline \multicolumn{1}{c}{ Indikator } & \multicolumn{2}{c}{ Rata-rata Postes } \\
& Kelompok Pembelajaran \\
\cline { 3 - 3 } & Eksperimen & Kontrol \\
\hline Memahami Masalah & 5 & 5 \\
\hline $\begin{array}{l}\text { Diketahui } \\
\text { - Menuliskan yang diketahui } \\
\text { dengan benar dan lengkap }\end{array}$ & & \\
\hline $\begin{array}{l}\text { Kecukupan Data } \\
\text { - } \begin{array}{l}\text { Menuliskan kecukupan } \\
\text { data dengan benar }\end{array}\end{array}$ & 9.96 & 9.8 \\
\hline Merencanakan Penyelesaian & & \\
\hline $\begin{array}{l}\text { Menuliskan cara yang } \\
\text { digunakan untuk memcahkan } \\
\text { masalah dengan benar dan } \\
\text { lengkap }\end{array}$ & 12.2 & \\
\hline Menjalankan Rencana & & \\
\hline $\begin{array}{l}\text { Menuliskan aturan } \\
\text { penyelesaian dengan hasil } \\
\text { benar dan lengkap }\end{array}$ & 5.96 & \\
\hline Memeriksa Kembali & & \\
\hline $\begin{array}{l}\text { Menuliskan pemeriksaan } \\
\text { secara benar dan lengkap }\end{array}$ & 6 & 1.8 \\
\hline
\end{tabular}

Berdasarkan uraian di atas, dapat dilihat bahwa rata-rata tes kemampuan pemecahan masalah matematis siswa kelas eksperimen tiap indikator lebih besar dari pada rata-rata tes kemampuan pemecahan masalah matematis siswa kelas kontrol. Hal ini menunjukkan bahwa adanya pengaruh yang lebih baik pada siswa yang diberi pembelajaran pendekatan matematika realistik.

Hasil pengujian menunjukkan bahwa kelompok data kemampuan pemecahan masalah matematis siswa berasal dari populasi yang berdistribusi normal dengan varians data homogen, 
Vol. 12, No. 1, Juni 2020

Tabel 5. Uji ANAVA Kemampuan Pemecahan

Masalah Matematis Siswa

Test of Between-Subjects Effects

\begin{tabular}{|c|c|c|c|c|c|}
\hline \multicolumn{6}{|c|}{ Dependent Variable: Kemampuan Pemecahan Masalah Matematis } \\
\hline Source & $\begin{array}{l}\text { Type III } \\
\text { Sum of } \\
\text { Squares }\end{array}$ & Df & $\begin{array}{c}\text { Mean } \\
\text { Square }\end{array}$ & $\mathrm{F}$ & Sig. \\
\hline $\begin{array}{l}\text { Corrected } \\
\text { Model }\end{array}$ & $6292.141^{\mathrm{a}}$ & 5 & 1258.428 & 79.949 & .000 \\
\hline Intercept & 189522.111 & 1 & 189522.111 & $1.204 \mathrm{E} 4$ & .000 \\
\hline KAM & 3206.111 & 1 & 3206.111 & 203.686 & .000 \\
\hline Pembel & 1834.600 & 2 & 917.300 & 58.277 & .000 \\
\hline $\begin{array}{l}\text { KAM * } \\
\text { Pembel }\end{array}$ & 35.110 & 2 & 17.555 & 1.115 & .337 \\
\hline Error & 692.579 & 44 & 15.740 & & \\
\hline Total & 243932.000 & 50 & & & \\
\hline $\begin{array}{l}\text { Corrected } \\
\text { Total }\end{array}$ & 6984.720 & 49 & & & \\
\hline
\end{tabular}

Berdasarkan hasil uji ANAVA, kemampuan pemecahan masalah matematis siswa pada tabel 4.11. maka $\mathrm{F}$ hitung pada faktor pendekatan pembelajaran matematika realistik adalah 203.686 dan nilai signifikan (sig) $\alpha=0.000$. Karena taraf nilai signifikan kemampuan pemecahan masalah siswa lebih kecil dari $\alpha=0.05$ maka dapat disimpulkan bahwa terdapat pengaruh pendekatan pembelajaran matematika realistik terhadap kemampuan pemecahan masalah matematis siswa.

Untuk interaksi dari Tabel 5, terlihat bahwa faktor pembelajaran dan KAM hasil analisis, diperoleh nilai $\mathrm{F}$ untuk interaksi pembelajaran dan KAM yaitu 1.115 dan nilai signifikansi yaitu 0.337. Karena nilai signifikansi lebih besar dari nilai taraf signifikan 0,05 jadi tidak cukup bukti untuk menolak Ho dengan kata lain Ho diterima, berarti tidak terdapat interaksi pendekatan pembelajaran dan KAM terhadap kemampuan pemecahan masalah matematis siswa. Lebih jelas dapat dilihat pada Gambar 4 berikut ini.

Estimated Marginal Means of KEMAMPUAN Pemecahan Masalah
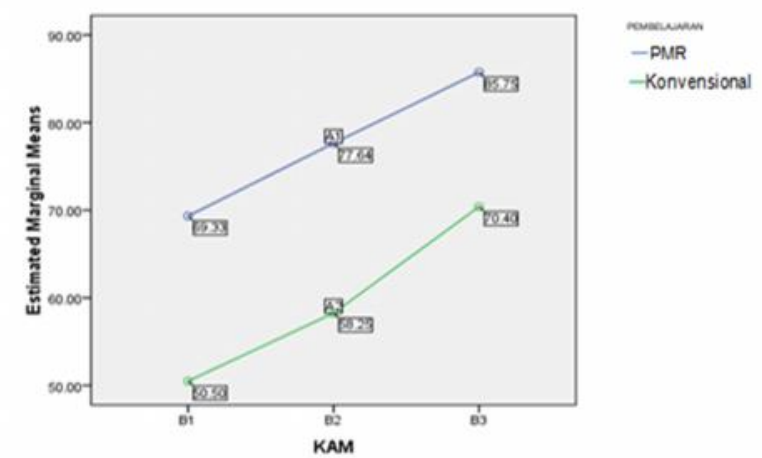

Gambar 4. Interaksi Pendekatan Pembelajaran dan Kemampuan Awal Matematika Terhadap Kemampuan Pemecahan Masalah Siswa

Gambar 4 memperlihatkan bahwa pendekatan pembelajaran matematika realistik lebih berpengaruh dalam mencapai potensi kemampuan pemecahan masalah matematis siswa karena skor rataan yang diperoleh siswa di kelas ini lebih tinggi dibandingkan dengan skor rataan yang diperoleh di pembelajaran konvensional. Sehingga tidak terdapat interaksi pendekatan pembelajaran dankemampuan awal matematika siswa terhadap kemampuan pemecahan masalah matematis siswa.

Berdasarkan beberapa uraian diatas maka telah didapatkan jawaban tentang apa yang menjadi pertanyaan-pertanyaan yang harus diteliti dalam penelitian ini. Bahwa antara kedua garis tidak berpotongan atau bersinggungan maka kuat dugaan tidak terdapat interaksi antara model pembelajaran dan KAM terhadap kemampuan pemecahan masalah matematis siswa.

\section{PEMBAHASAN}

Berdasarkan Tes KAM dalam penelitian ini digunakan untuk menentukan kelompok KAM siswa berdasarkan kelompok KAM tinggi, sedang, dan rendah. Pengelompokkan KAM juga digunakan untuk menjawab permasalahan yang terkait dengan kemampuan berpikir kreatifdan kemampuan pemecahan masalah matematis yang diberi pembelajaran dengan pendekatan matematika realistikdan pembelajaran biasa.

Dalam memperoleh pembelajaran yang baru, siswa harus menggunakan pengetahuan dan pengalaman yang telah dimilikinya untuk mengikuti pembelajaran selanjutnya. Hal-hal yang telah dipelajari tersebut akan digunakan untuk menghadapi atau memecahkan hal yang baru. Untuk itu, agar siswa dapat mencapai hasil belajar yang baik terlebih dahulu diberikan tes kemampuan awal matematis agar dapat mengetahui kemampuan pengetahuan, keterampilan, dan kompetensi apa yang telah dimiliki siswa pada saat akan mengikuti pengajaran.

Dengan demikian tinggi atau luasnya pengetahuan, informasi, pengalaman dan kemampuan siswa yang akan digunakan untuk mempelajari pembelajaran berikutnya diharapkan akan memperbesar kemungkinan dalam meningkatkan kemampuan berpikir kreatif dan kemampuan pemecahan masalah matematis siswa.

Siswa yang kreatif berbeda dengan siswa yang kurang kreatif. Siswa yang kreatif lebih condong untuk mengemukakan pertanyan-pertanyaan yang dapat membantunya untuk menemukan jawaban-jawaban ketika menyelesaikan sebuah masalah. Siswa akan mudah memiliki kemampuan berpikir kreatif dalam matematika jika ketika ia menerima pelajaran, cara yang diberikan kepadanya dapat menumbuhkembangkan daya berpikir dan berkreativitasnya melalui sebuah strategi yang digunakan guru. Seperti yang telah dijelaskan pada halaman sebelumnya, bahwa berpikir kreatif adalah pola berpikir yang didasarkan pada suatu cara yang mendorong untuk menghasilkan produk yang kreatif. Artinya siswa yang bepikir kreatif akan selalu mencoba untuk menemukan penyelesaian masalah yang berbeda dari biasanya dan bervariasi.

Jadi, maksud dari kemampuan berpikir kreatif dalam matematika adalah kemampuan yang di miliki seseorang untuk dapat meyelesaikan sebuah permasalahan matematika dengan memiliki cara penyelesaian jawaban yang bervariasi dan beragam dengan memperhatikan pula kualitas jawabannya. 
Sehingga, pembelajaran matematika dirasakan tidak monoton dan membosankan.

Menurut Purba, Surya dan Syahputra (2017) menganalisis bahwa siswa kesulitan dalam mengerjakan soal FPB karena siswa tidak dapat melakukan operasi perkalian dan pembagian. Ini disebabkan karena siswa belum memiliki kemampuan berpikir kreatif. Nehe, Surya, dan Syahputra (2017) menyatakan bahwa kemampuan berpikir kreatif siswa dapat meningkatkan pemahaman matematika siswa. Sementara menurut Simbolon, Manullang, Surya, dan Syahputra (2017) mengatakan bahwa dengan kemampuan berpikir kreatif akan meningkatkan kemampuan pemecahan masalah siswa juga.

Berdasarkan hasil uji ANAVA, kemampuan berpikir kreatif siswa dengan nilai signifikan (sig) $\alpha=$ 0,000. Karena taraf nilai signifikan kemampuan berpikir kreatif siswa lebih kecil dari $\alpha=0,05$ maka dapat disimpulkan bahwa terdapat pengaruh pendekatan pembelajaran matematika realistik terhadap kemampuan berpikir kreatif siswa.

Seperti yang telah dikemukakan sebelumnya, bahwa yang dimaksud dengan kemampuan pemecahan masalah matematis adalah kemampuan siswa dalam menyelesaikan suatu masalah.Siswa dikatakan telah mempunyai kemampuan pemecahan masalah matematis yang baikjika ia telah mampu: (1) mengidentifikasi unsur-unsur yang diketahui, dan ditanyakan; (2) merumuskan masalah matematis atau menyusun model matematis; dan (3) memilih dan menerapkan strategi untuk menyelesaikan masalah.

Pada penelitian ini dilakukan MTs Swasta Attaufiqurrahman Labuhan batu Utaradengan populasi seluruh siswa kelas VIII MTs Swasta AttaufiqurrahmanLabuhanbatu Utaradan sampel yang diambil secara acak (cluster sampling) untuk dijadikan kelas eksperimen adalah VIII-1 dan kelas kontrol adalah VIII-2.

Adapun tujuan penelitian ini adalah menjawab rumusan masalah dan hipotesa (asumsi sementara) yaitu untuk mengetahui apakah kemampuan pemecahan masalah matematis dengan menggunakan pembelajaran pendekatan matematika realistik lebih baik dari pada pembelajaran biasa. Sebelum dilakukan uji statistik untuk hipotesisnya dengan menggunakan uji-t bantuan SPSS 23, maka dilakukan uji normalitas dan homogenitas data postes tersebut. Hasil menunjukkan normal dan homogen berdasarkan uji normalitas dan homogenitas menggunakan bantuan SPSS 23.

Sinaga, Surya dan Syahputra (2017) menemukan bahwa terdapat pengaruh pendekatan Realistic Matemathic Education (RME) terhadap kemampuan komunikasi matematis siswa berbasis problem solving. Sofiyah, Surya dan Syahputra (2017) mengatakan bahwa pendekatan pendidikan matematika realistik dapat meningkatkan atau membangun kemampuan pemecahan masalah matematis dan kemandirian belajar siswa. Menurut Syahputra (2017) perlu diadakan pengembangan suatu model pembelajaran berbasis pemecahan masalah untuk mengkontruksi berpikir tingkat tinggi dalam pembelajaran matematika di
SMA/MA. Siregar, Surya dan Syahputra (2017) siswa perlu memiliki kemampuan pemecahan masalah agar siswa mampu memilih dan menyusun strategi yang tepat untuk memecahkan soal. Landong, Surya dan Syahputa (2017) mengatakan bahwa kemampuan pemecahan masalah dapat meningkatkan karakter positif dari siswa. Maka, penting kiranya untuk selalu meningkatkan kemampuan pemecahan masalah siswa. Sementara Menurut Putri, Syahputra, dan Surya (2017) penting kiranya untuk memperbaiki kemampuan pemecahan masalah siswa di SMP Negeri 2 Lubuk Pakam.

Berdasarkan hasil uji ANAVA, kemampuan pemecahan masalah matematis siswa pada tabel 4.11. maka nilai signifikan (sig) $\quad \alpha=0,000$. Karena taraf nilai signifikan kemampuan pemecahan masalah siswa lebih kecil dari $\alpha=0,05$ maka dapat disimpulkan bahwa terdapat pengaruh pendekatan pembelajaran matematika realistik terhadap kemampuan pemecahan masalah matematis siswa.

Pada penelitian ini kemampuan siswa juga diperoleh berdasarkan nilai KAM, yang mana pengelompokan siswa tersebut didasarkan pada kemampuan tinggi, sedang dan rendah. Faktor kemampuan siswa yaitu KAM dikaitkan dengan faktor pembelajaran. Sehingga dapat dilihat bagaimana keterkaitan antara KAM dan pembelajaran terhadap kemampuan berpikir kreatif dan kemampuan pemecahan masalah matematis siswa. Siswa akan menggunakan pengetahuan yang dimilikinya sebelumnya. Hal ini sesuai dengan teori perkembangan kognitif oleh Piaget, Piaget mengatakan bahwa pengetahuan dibentuk oleh individu itu sendiri. Siswa dapat belajar dengan pengetahuan yang dimiliki sebelumnya. Selanjutnya Vygostky mengatakan bahwa pembelajaran terjadi jika anak bekerja atau belajar menangani tugas-tugas yang belun dipelajarinya namun masih dalam jangkauan kemampuannya sendiri.

Dari hasil analisis data kemampuan berpikir kreatif matematis di lapangan diperoleh dengan tingkat signifikansi sebesar 0,488. Dengan demikian H0 diterima dan $\mathrm{H} 1$ ditolak. Yang berarti tidak terdapat interaksi antara pembelajaran dan kemampuan awal matematika siswa terhadap kemampuan berpikir kreatif matematis siswa. Hal ini dapat diartikan bahwa interaksi antara pembelajaran dan kemampuan awal matematika siswa (KAM) tidak memberikan pengaruh signifikan terhadap kemampuan pberpikir kreatif matematis siswa.

Sama halnya dengan kemampuan pemecahan masalah siswa hasil analisis data yang diperoleh di lapangan menunjukkan bahwa tingkat signifikansi sebesar 0,337. Dengan demikian H0 diterima dan H1 ditolak. Yang berarti tidak terdapat interaksi antara pembelajaran dan kemampuan awal matematika siswa terhadap kemampuan pemecahan masalah siswa.

Hasil penelitian ini menunjukkan bahwa secara signifikan tidak terdapat interaksi antara pembelajaran dan kemampuan awal matematika (KAM) terhadap kemampuan berpikir kreatif dan kemampuan pemecahan masalah matematis.Artinya pembelajaran dalam mempengaruhi kemampuan berpikir kreatif dan 
kemampuan pemecahan masalah matematissiswa tidak tergantung pada kemampuan awal matematika siswa (pembelajaran dan KAM tidak saling mempengaruhi). Dengan kata lain, pengaruh kemampuan berpikir kreatif dan kemampuan pemecahan masalah matematissiswa disebabkan oleh pembelajaran yang digunakan dan tidak tergantung pada kemampuan awal matematika siswa. Sehingga dapat disimpulkan bahwa dengan tidak terdapatnya interaksi makapembelajaran dan kemampuan awal matematika siswa tidak secara bersama-sama memberikan pengaruh terhadap kemampuan berpikir kreatif dan kemampuan pemecahan masalah matematissiswa.

\section{KESIMPULAN}

Berdasarkan Berdasarkan hasil analisis data dan pembahasan dalam penelitianini, maka dikemukakan beberapa kesimpulan sebagai berikut:

1. Terdapat pengaruh pendekatan pembelajaran matematika realistik terhadap kemampuan berpikir kreatif siswa. Berdasarkan hasil analisis diperoleh Fhitung $=21,214>$ Ftabel $=3,02$ dengan sig $=$ 0,000. Karena taraf sig. lebih kecil dari 0.05, sehinga Ho ditolak dan H1 diterima. Maka dapat disimpulkan terdapat pengaruh pendekatan pembelajaran matematika realistik terhadap kemampuan berpikir kreatif siswa.

2. Terdapat pengaruh pendekatan pembelajaran matematika realistic terhadap kemampuan pemecahan masalah matematis siswa. Berdasarkan hasil analisis diperoleh Fhitung $=203,686>$ Ftabel $=3,02$ dan dengan sig $=0.000$. Karena taraf sig. lebih kecil dari 0.05, sehinga Ho ditolak dan H1 diterima. Maka dapat disimpulkan terdapat pengaruh pendekatan pembelajaran matematika realistic terhadap kemampuan pemecahan masalah matematis siswa.

3. Tidak terdapat interaksi antara pembelajaran dan kemampuan awal matematika terhadap kemampuan berpikir kreatif siswa. Berdasarkan hasil analisis diperoleh Fhitung $=0,730<$ Ftabel $=3,02$ dan dengan sig $=0,488$. Karena taraf sig lebih besar dari nilai taraf signifikan 0,05 , sehinga Ho diterima.

4. Tidak terdapat interaksi antara pembelajaran dan kemampuan awal matematika terhadap kemampuan pemecahan masalah matematis siswa. Berdasarkan hasil analisis diperoleh Fhitung $=1,115<$ Ftabel $=$ 3,02 dan dengan sig $=0,337$. Karena taraf sig. lebih besar dari nilai taraf signifikan 0,05 sehinga Ho diterima.

\section{UCAPAN TERIMA KASIH}

Pada kesempatan ini, penulis mengucapkan terima kasih yang tulus dan penghargaan yang setinggitingginya kepada semua pihak yang telah membantu penulis, kepada keluarga yang telah mendukung penulis dalam segala hal. Bapak Prof. Dr. Asmin, M.Pd selaku dosen pembimbing I, ibu Dr. Faiz Ahyaningsih, S.Si., M.Si selaku dosen pembimbing II, Kepala Madrasah dan guru-guru serta staf administrasi MTs Swasta At-Taufiqurrahman yang telah memberikan izin dan kesempatan kepada penulis untuk melakukan penelitian di sekolah tersebut.

\section{REFERENSI}

Asis M., Arsyad N., \& Alimuddin. 2015. Profil kemampuan spasial dalam menyelesaikan masalah geometri siswa yang memiliki kecerdasan logis matematis tinggi ditinjau dari perbedaan gender, Daya Matematis: Jurnal Inovasi Pendidikan Matematika. 3(1): p. 1-10.

Dilla, S. C., Hidayat, W., dan Rohaeti, E. E. 2018. Faktor Gender Dan Resiliensi Dalam Pencapaian Kemampuan Berpikir Kreatif Matematis Siswa SMA. Journal Of Medives. 2(1): p.129-139.

Firmansyah, A. M. 2017. Peran Kemampuan Awal Matematika Dan Belief Matematika terhadap Hasil Belajar. Jurnal Pendidikan Matematika. 1(1): p. 5568.

Fitri, S., Syahputra, E., \& Syahputra, H. 2019. Blended Learning Rotation Model of Cognitive Conflict Strategy to Improve Mathematical Resilience in High School Students. International Journal of Scientific \& Technology Research, vol.1, no. 1.

Fitri, S., \& Zahari, C.L. 2018. The implementation of blended learning to improve understanding of mathematics, The Sixth Seminar Nasional Pendidikan Matematika Universitas Ahmad Dahlan 2018: IOP Conf. Series: Journal of Physics: Conf. Series $1188 \quad$ (2019) 012109, 2018, doi:10.1088/1742-6596/1188/1/012109.

Glantz, M. \& Johnson, J. 2002. Resilience and development positive life adaptation. Kluwer Academic Publisher: USA.

Khotimah, H. 2013. Meningkatkan Hasil Belajar Geometri Dengan Teori Van Hiele, Makalah disajikan dalam Seminar Nasional Matematika dan Pendidikan Matematika dengan tema "Penguatan Peran Matematika dan Pendidikan Matematika untuk Indonesia yang LebihBaik". UNY, Yogyakarta.

Lee, G., dan Wilder. 2010. Development af an Instrument for Measuring Cognitive Conflict in Secondary-Level Science Classes. Journal Of Research In Science Teaching. 40(6): p.585-603.

Maier dan Peter, H. 1996. Spatial Geometry and Spatial Ability - How To Make Solid Geometry Solid.

National Academy of Science. 2006. Learning to Think Spatially. Washington DC: The National Academics Press.

Prabowo, A dan Ristiani, E. 2011. "Rancang Bangun Instrumen Tes Kemampuan Keruangan Pengembangan Tes Kemampuan Keruangan Hubert Maier dan Identifikasi Penskoran Berdasar Teori Van Hielle”, JURNAL KREANO. 2(2): p. 72-87.

Ristontowi. 2013. Kemampuan Spasial Siswa melalui Pendekatan Pendidikan Matematika Realistik Indonesia dengan Media Geogebra, Makalah disajikan dalam Seminar Nasional Matematika dan Pendidikan Matematika dengan tema "Penguatan Peran Matematika dan Pendidikan Matematika 
Vol. 12, No. 1, Juni 2020

untuk Indonesia yang Lebih Baik". UNY, Yogyakarta.

Syahputra, E. 2013. Peningkatan Kemampuan Spasial Siswa Melalui Penerapan Pembelajaran Matematika Realistik, Jurnal Cakrawala Pendidikan. p. 353-364.

Yeager, D. dan Dweck, C. 2012. Mindsets That Promote Resilience: When Students Believe That Personal Characteristics Can Be Developed. Educational Psychologist. 47: p.302-314. 